\title{
СУЧАСНI АСПЕКТИ ФУНКЦІОНУВАННЯ ТА ПЕРСПЕКТИВИ РОЗВИТКУ КУРОРТУ МОРШИН
}

Р.І. Яцишин ${ }^{1}$, Н.В. Чернюк', П.Р. Герич1, І.С. Михалойко ${ }^{1}$ С.Д. Чайковський², О.В. Мельник², Б.Є. Магасевич²

1/вано-Франківський національний медичний університет, м. Івано-Франківськ ${ }^{2} Д П$ «Санаторій „Моршинкурорт“», м. Моршин

Резюме. Метою огляду було поглиблення знань про санаторно-курортний фонд м. Моршина, його специфіку й напрями оздоровлення, спектр послуг та інновацій у санаторно-лікувальній справі. Лікувальні й оздоровчі чинники курорту мають високу терапевтичну цінність, медичну та соціально-економічну ефективність. Проте необхідне проведення подальших досліджень ефективності й лікувальних властивостей мінеральних вод Моршинського родовища та розширення показань до їх застосування, що забезпечить можливість подальшого розвитку курорту як важливого лікувально-реабілітаційного комплексу.

Ключові слова: мінеральні води, курорт Моршин, лікування, профілактика, реабілітація.

\section{Modern aspects of functioning and prospects of Morshyn resort development}

R.I. Yatsyshyn', N.V. Cherniuk', P.R. Gerych', I.S. Mykhaloiko', S.D. Chaikovskii'², O.V. Melnyk², B.E. Magasevych ${ }^{2}$

${ }^{1}$ Ivano-Frankivsk National Medical University, Ivano-Frankivsk

${ }^{2} S E$ «Sanatorium „Morshynkurort"», Morshyn

Abstract. The purpose of this review was to deepen knowledge about the sanatorium-resort fund of Morshyn, its specifics and areas of rehabilitation, the range of services and innovations in the sanatorium-medical business. Therapeutic and health factors of the resort have a high therapeutic value, medical and socio-economic efficiency. However, it is necessary to conduct further research on the effectiveness and therapeutic properties of mineral waters of the Morshyn deposit and expand the indications for their use, which will provide an opportunity for further development of the resort.

Keywords: mineral waters, Morshyn resort, treatment, prevention, rehabilitation.

УДК: 911.3: 33:338.48

DOI: $10.31793 / 2709-7404.2021 .2-1.52$

() Р.І. Яцишин, Н.В. Чернюк, П.Р. Герич, І.С. Михалойко, С.Д. Чайковський, О.В. Мельник, Б.Є. Магасевич

Надійшла до редакції 05.03.2021

Адреса для листування (Correspondence): Івано-Франківський національний медичний університет, вул. Галицька, 2, м. Івано-Франківськ, 76018, Україна. E-mail: zdovado@ukr.net 


\section{Вступ}

Упродовж останніх років актуальними є реабілітаційні та профілактичні напрями медицини. Зокрема, медична реабілітація передбачає комплексний підхід, що включає способи прискорення реституції, стимуляції реперативно-регенеративних процесів, виявлення та зміцнення компенсаторних механізмів, корекції загальної резистентності організму та імунітету. У зв'язку із цим все частіше популярності набуває широке використання мінеральних лікувальних вод для медичної реабілітації, профрілактики захворювань та оздоровлення населення. На курортах України використовуються мінеральні води різного хімічного складу, мікробного ценозу, біологічної активності [1].

Дочірнє підприємство (ДП)«Санаторій „Моршинкурорт“» знаходиться в центрі відомого в Україні та заїі межами бальнеологічного курорту Моршин, серед тисячі гектарів екологічно чистих Карпатських лісів [2]. Володіючи джерелами мінеральних вод 3 унікальними лікувальними властивостями, сучасною медичною базою, висококваліфікованим медичним персоналом, комфрортним номерним фрондом і вдалим розташуванням спальних корпусів у лісопарковій зоні, ДП «Санаторій „Моршинкурорт“» створюе сприятливі умови для вдалого відпочинку, ефективного лікування, реабілітації та профрілактики [3].

Метою огляду було поглиблення знань про санаторно-курортний фонд м. Моршина, його специфіку й напрями оздоровлення, спектр послуг та інновацій у санаторно-лікувальній справі.

Ефективність та лікувальні властивості мінеральних вод Моршинського родовища. Місто Моршин цілком відповідає поняттю міста-курорту, тобто міста, у якому основною містоутворювальною галуззю є курортно-рекреаційне господарство [4]. Моршин добре відомий як один із кращих бальнеотерапевтичних курортів країни, розташований у затишній долині серед прикарпатських заповідних лісів [5].

Територія м. Моршина має статус заповідної зони, на якій заборонені будь-які роботи, що можуть погіршити екологічну ситуацію. Це рекреаційний район, де зберігся первозданним дубово-буковий ліс. Сприятливі природно-кліматичні умови доповнюють загальний комплекс лікувальних заходів курорту [6].

У геологічному відношенні Моршинське родовище займає чималу територію біля м. Моршин. Але вода виходить на поверхню лише з декількох джерел, розташованих у букових лісах на території курортної зони [3].
Становленню та розвитку ДП «Санаторій „Моршинкурорт“» сприяли його головні лікувальні чинники - джерела мінеральних вод (розсоли) № 1, 4, 6 [7].

Ще із середини минулого століття провідні вчені України активно займалися вивченням лікувальних властивостей мінеральних вод курорту Моршин. Так, свій науковий шлях у Моршині починав нині академік Національної академії медичних наук України, професор Пиріг Л.А., який працював заступником головного лікаря санаторію «Мармуровий палац» і опублікував низку наукових досліджень і книгу «Курорт Моршин» (1965), у яких висвітлив застосування мінеральних вод курорту в гастроентерології [8].

Великий внесок у розвиток курорту зробив д. мед. н., професор Івано-Франківського національного медичного університету (ІФНМУ) Середюк Н.М., який довів лікувальні властивості мінеральних вод курорту при виразковій хворобі та хронічному гепатиті і на підставі цих досліджень захистив кандидатську та докторську дисертації [9].

Значний внесок у становлення курорту також зробив д. мед. Н., професор ІФНМУ Міщук В.Г., який присвятив вивченню ефективності мінеральних вод у лікуванні хронічного панкреатиту та хронічного гастриту свої кандидатську та докторську дисертації, опублікував монографію «Мінеральні води України», методичні рекомендації «Медична реабілітація в санаторно-курортних закладах України» (www.ifnmu.edu.ua).

Науковці сучасності продовжують розширювати показання до застосування мінеральних вод курорту Моршин. Нещодавно в Українському НДІ медичної реабілітації та курортології М03 України було проведено експериментальне дослідження, яке показало позитивний вплив мінеральних вод курорту Моршин на лікування неалкогольної жирової хвороби печінки, а саме мінеральна вода джерела № 6 має позитивний вплив на структурно-функціональну характеристику печінки, що визначається в різкому послабленні чи зникненні ознак жирової інфільтрації, зменшенні ознак дистрофії гепатоцитів та відновленні рівномірної активності ферментів за всім зрізом часточки [10].

Науковці Національного медичного університету ім. Данила Галицького довели ефективність застосування мінеральної води джерела № 6 у стоматології, а саме що мінеральна вода джерела № 6 здатна зменшити запальні явища в тканинах пародонта та усунути місцевий імунний дисбаланс порожнини рота без будь-яких інших медикаментозних засобів [11]. 
Загалом показання до застосування мінеральних вод досить широкі і доведені численними дослідженнями. Основні 3 них наведено нижче.

Джерело № 1 - це шахтний колодязь глибиною близько 50 м із хлоридно-сульфатно-натрієвою водою. Його вода високомінералізована (ропа, розсол). Загальна мінералізація води 3 глибиною колодязя збільшується із 16 г/л (поверхневий шар) до 400 г/л (придонний шар) [12]

Ропа поверхневого шару використовується для зовнішнього застосування, ропа придонного шару - внутрішньо. Істотно доповнюють терапевтичну цінність води мікроелементи (мідь, цинк, залізо, алюміній, стронцій, кобальт) [2]. Вода цього мінерального джерела: зменшує запальні процеси в травному тракті, посилює годинну напругу секреції, підвищує кислотність і травну силу соку, активно стимулює евакуаторну функцію шлунка, позитивно впливає на процеси всмоктування, що необхідно при лікуванні хворих із післярезекційним синдромом, захворюваннями кишківника з ознаками порушення всмоктування, у гарячому вигляді сповільнює моторну функцію кишківника, запобігає процесам бродіння та розпаду в товстій кишці, перешкоджає всмоктуванню продуктів патологічного розпаду, виводить 3 організму радіонукліди, підсилює жовчоутворення і жовчовиділення, попереджує застій жовчі в жовчному міхурі, усуваючи одну з причин утворення жовчних каменів [13].

У результаті лікування мінеральною водою джерела № 1 підвищуються окисні процеси, що регулює жировий обмін аліментарного, нейрогенного та ендокринного походження [3].

Значно розширює діапазон дії лікувальних властивостей курорту та створює умови для розвитку його як поліфункціонального рекреаційного комплексу джерело № 4. Вода цього джерела за мінералізацією близька до дощової (0,17 г/л), за хімічним складом - гідрокарбонатно-кальцієва. Крім зазначених інгредієнтів, до її складу входять калій, натрій, магній, залізо, сульфати [12]. Крім цього, вода радіоактивна, 3 постійним вмістом родону і підвищеним вмістом розчиненого кисню. Лікувальні властивості мінеральної води джерела № 4 ґрунтуються на правильній кристалічній будові та особливостях ії хімічного мікробного складу фрізіологічної дії: низька мінералізація, слабка радіоактивність, високий вміст органічного вуглецю, азоту, специфрічна мікросрлора, вплив на енергетичний обмін, розподіл води в організмі, обмін іонів натрію і калію, на парціальні процеси в нирках [7].

Вода цього мінерального джерела має низку таких властивостей: нормалізуюче впливає на функціональний стан нирок; сприяє олужненню сечі, вимиванню солей та відходженню дрібного каміння, зменшує небезпеку каменеутворення та попереджує літогенність сечі; виводить радіонукліди; стимулює перебіг окислювальних процесів у тканині печінки; має сечогінну, спазмолітичну, знеболювальную дію; усуває запальний процес у нирках, сечовидільних шляхах; покращує клубочкову фрільтрацію, канальцеві секрецію та реабсорбцію в нирках; у поєднанні з грязьовими ректальними тампонами та озокеритовими аплікаціями усуває венозний застій у малому тазі; сприяє розсмоктуванню запальних інсрільтратів; стимулююче впливає на рухову функцію гладких м'язів [14]. Спостерігається терапевтична есрективність мінеральної води джерела № 4 при сечокам'яній хворобі, хронічному пієлонесриті, сечокислому діатезі, подагрі, остеоартрозі [7].

Найкращий лікувальний ефект можна відчути саме при комплексному лікуванні, яке поєднує внутрішній прийом води (питтєвий режим, кишкові зрошення, гідроколонотерапія) та зовнішнє ї застосування (гідролазеротерапія та мінеральні ванни) [6].

Джерело № 6 використовується з 1968 р. За хімічним складом вода (ропа) сульфатно-хлоридна, натрієво-магнієво-калієва із загальною мінералізацією до 238 г/л, характеризується високим вмістом сульфатів магнію і калію [3].

Під впливом курсового лікування мінеральною водою джерела № 6 підвищується артеріальний притік і відтік крові з печінки, зменшується тиск у басейні легеневої артерії. Зростання інтенсивності печінкового кровообігу сприяє зменшенню тканинної гіпоксії печінкових клітин, чим покращує їх функцію [13].

Наявність у воді іонів калію і магнію сприятливо впливає на водно-електролітний обмін, кислотно-лужну рівновагу в організмі людини, на метаболізм серцевого м'яза, забезпечує необхідну кількість магнію, який сприяє нормалізації біоценозу товстої кишки за рахунок зростання в її вмісті біфідо- та лактобактерій, зменшення кількості умовно-патогенної мікрофрлори, природно знижує інтоксикацію організму та відіграє важливу роль у життєдіяльності організму [15].

Лікування мінеральною водою джерела № 6 сприяє нормалізації обміну речовин - позитивно впливає на рівень холестерину, В-ліпопротеїдів, зменшує рівень цукру в крові та підвищує толерантність до глюкози у хворих на цукровий діабет, підвищує окисні процеси, тож приводить до втрати ваги в людей з ожирінням [12].

Мінеральні води джерел № 1 та № 6 відносять до радіоблокаторів - містять елементи К, $\mathrm{Na}, \mathrm{Mg}$, що конкурують із радіонуклідами цезію 
і сприяють швидкому виведенню його з організму. Завдяки протизапальному ефекту, збільшенню об'єму рідини в порожнині кишківника мінеральні води цих джерел сприяють промиванню стінки кишківника, видаленню бактеріальних токсинів, радіонуклідів, недоокислених продуктів обміну речовин, нормалізують показники секреторної та кислоутворювальної функції шлунка [3].

Сучасні аспекти функціонування ДП «Санаторій „Моршинкурорт“». ДП «Санаторій „Моршинкурорт“» — лідер у лікуванні захворювань органів травлення в дорослих та дітей (печінки, підшлункової залози, кишківника, шлунка) та цукрового діабету. 32018 року «Моршинкурорт» відкриває нові санаторно-курортні напрямки лікування: лікування захворювань органів опорно-рухової системи, органів дихання, нервової системи, серцево-судинної системи, а також нефрологічних, урологічних та гінекологічних захворювань [1]. ДП «Санаторій „Моршинкурорт“» має можливість одночасно приймати на лікування та оздоровлення понад 1700 гостей, що становить 90\% потужності всього курорту [2].

ДП «Санаторій „Моршинкурорт“» складається з окремих санаторіїв («Черемош», «Дністер», «Світанок», «Перлина Прикарпаття», «Лаванда»), які компактно розміщуються в лісовій зоні міста [3].

Лікувально-діагностичний центр «Моршинкурорту» - це високого рівня лікувально-діагностична база, що забезпечує відвідувачів курорту комплексним обстеженням організму та професійним лікуванням. Тут працює кваліфрікований медперсонал, застосовується найсучасніша медична апаратура [1]. Лікувально-діагностичний центр розрахований на 1200 відвідувань на день. До послуг відвідувачів центру пропонується понад 250 методик діагностики, а також консультації лікарів-спеціалістів усіх основних напрямків [3].

Найкращий та найдовготриваліший ефект у лікуванні на курорті Моршин — це поєднання внутрішнього вживання моршинської мінеральної води з іншими лікувальними фракторами курорту. Прийом процедур у бальнеолікарні - це одна з основних складових комплексного санаторно-курортного лікування [15].

Мінеральні (хлоридно-натрієві) та мінерально-комбіновані ванни - це водолікувальні процедури, при яких на організм пацієнта здійснює температурний, механічний і хімічний вплив мінеральна вода та розчинені в ній лікувальні засоби, суміші або відвари трав. Мінеральна ванна і розчинені в ній лікувальні речовини (хвоя, бішофіт, валеріана, йодобром та інші добавки) мають стимулювальну і зміцнювальну дію, знімають м'язові й суглобові болі, здійснюють регулювальний вплив на фрунцціональний стан центральної нервової системи, викликають імунологічну перебудову в організмі, змінюють перебіг обмінних процесів, покращують тонічні властивості венозної стінки й мікроциркуляцію та гемодинаміку у внутрішніх органах, сприяють покращенню відтоку крові 3 кінцівок при венозному застої, сприяють розслабленню гладких м'язів органів травлення, тим самим покращують моторно-евакуаторну функцію травного тракту [16].

Крім того, ванни застосовують для покращення стану після травм, переломів, опіків, паралічів. Залежно від виду ванна може заспокоювати або тонізувати нервову систему і знімати стрес, позитивно впливає на весь організм і, крім лікувального, має добрий косметичний ефект — омолоджує й освіжає шкіру, відновлює її пружність і попереджує старіння. Мінеральні ванни мають терапевтичну дію: судинорозширювальну, метаболічну, імуностимулювальну, протизапальну $[17,18]$. Лікувальні ванни доцільно призначати і при остеоартрозі, кістково-метаболічних порушеннях.

У центральній частині курорту розташований бювет мінеральних вод, де одночасно можуть приймати мінеральну воду близько 6 тис. осіб. Приготування та підігрів води здійснюється в спеціальному відділенні бювету під постійним контролем гідрохімічної лабораторії та санітарних установ [19].

Перспективи розвитку ДП «Санаторій „Моршинкурорт“». ДП «Санаторій „Моршинкурорт“» невпинно розвивається. Так, із 2019 року відкрито нові реабілітаційні відділення, які здійснюють:

- м'язово-скелетну реабілітацію для хворих у підгострому періоді після операцій на опорно-руховому апараті, з ревматологічними захворюваннями, у підгострому періоді опіків;

- кардіопульмональну реабілітацію для хворих у підгострому періоді інфаркту міокарда, після пролікованої нестабільної стенокардії, у підгострому періоді після операцій на серці, у підгострому періоді хронічних захворювань легень, у підгострому періоді після операцій на легенях, у тому числі з приводу гнійних процесів нетуберкульозного характеру;

- соматичну реабілітацію для хворих у підгострому періоді після оперативних втручань на органах сечостатевої системи, у підгострому періоді після оперативних втручань на жіночих статевих органах, у підгострому періоді після оперативних втручань на органах травлення;

- нейрореабілітацію для хворих у підгострому періоді після перенесених інсультів, у підгострому періоді після черепно-мозкових травм;

- медико-психологічну реабілітацію учасників АТО з порушеннями адаптації, розладами, 
пов'язаними із споживанням їжі, неорганічними розладами сну, соматоформними розладами, неврастенією [1].

На сучасному етапі активну участь у вивченні лікувальних та профрілактичних чинників ДП «Санаторій „Моршинкурорт“» беруть науковці декількох кафедр Івано-Франківського національного медичного університету: внутрішньої медицини № 1, клінічної імунології та алергології ім. академіка Є.М. Нейка, внутрішньої медицини № 2 та медсестринства, ендокринології, урології. Такий міждисциплінарний підхід сприятиме якісній, своєчасній та повноцінній реабілітації пацієнтів. Надзвичайно важливою є ідейна підтримка науковців Прикарпатської терапевтичної школи, яку очолює сучасний лідер та стратегічний організатор професор Яцишин Р.І. Це забезпечує есрективне впровадження результатів досліджень з урахуванням основних тенденцій розвитку сучасної науки [20].

\section{Висновки}

На підставі наведеного вище можна зробити такі висновки:

1. Лікувальні та оздоровчі чинники ДП «Санаторій „Моршинкурорт“» мають високу терапевтичну цінність, медичну та соціально-економічну ефективність.

2. Необхідне проведення подальших досліджень есективності й лікувальних властивостей мінеральних вод Моршинського родовища та розширення показань до їх застосування, що забезпечить можливість подальшого розвитку курорту.

3. На сьогодні використовується лише $10 \%$ добового дебету мінеральних вод курорту Моршин, отже, є велика перспектива його розвитку та впровадження нових реабілітаційних напрямів, що сприятиме превентивному й персоналізованому підходу до кожного пацієнта.

\section{Список використаної літератури}

1. Малахова C.М., Черепок О.О., Волох Н.В. Курортологія та курорти України: навч. посіб. для самостійної роботи студентів VI курсу медичних фракультетів при підготовці до практичних занять з навчальної дисципліни «Медична реабілітація». - Запоріжжя: ЗДму, 2019. - 105 c.

2. Головатий М.В. Екологічні загрози збалансованому розвиткові бальнеологічному курорту Моршин // Фізична географрія та геоморфологія. - 2015. - Вип. 4 (80), ч. І. - С. 52-57.

3. Кілінська К.Й., Смик О.С. Лікувально-оздоровчий комплекс «Моршин»: сучасні аспекти ффункціонування // Український географрічний журнал. - 2015. - № 1. - С. 58-61.

4. Рутинський М. Становлення курорту Моршин на ринку міжнародних оздоровчо-рекреаційних послуг // Вісник Львівського університету. Серія «Міжнародні відносини». - 2012. - Вип. 29. - С. 220-231.

5. Бронецький Р. Підходи до еколого-географрічної класифікації бальнеологічних ресурсів. Наукові записки Тернопільського 135 національного педагогічного університету імені Володимира Гнатюка. Серія «Географія». — Тернопіль: Тайп, 2010. - Вип. 1 (27). - С. 43-47.

6. Головатий М.В. Проблеми рекреаційного використання бальнеологічних курортів (на прикладі Львівської обл.) // Вісник Львівського університету. Серія географрічна. - 2014. - Вип. 42. - С. 78-85.

7. Матолич Б.М. Мінеральні води та курорти Львівщини. - Львів: Палітра Друку, 2003. - 96 с

8. Пиріг Л.А. Шлях медика до та у п'ятдесятирічній самореалізації в нефррології // Нирки. — 2020. — № 4. — С. 198-200.

9. Кушнір В.В., Середюк Н.М. Лікування і обстеження хворих на курорті Моршин. - К.: Медицина, 2010. - 66 с.

10. Заболотна І.Б., Насібуллін Б.А., Гуща С.Г., Драгомирецька Н.В., Михайленко В.Л. Експериментальне обгрунтування використання мінеральних вод курорту Моршин у лікуванні хворих на неалкогольну жирову хворобу печінки // Art of mеdicine. — 2018. — Bип. 3 (7). - C. 185-187.

11. Швець І.Є., Марков А.В., Мороз К.А., Пупін Т.І. Клініко-імунологічна еффективність мінеральної води курорту Моршин в комплексній терапії генералізованого пародонтиту у хворих з хронічним гастритом // Вісник проблем біології і медицини. - 2015. — Т. 4 (2). C. 364-366.

12. Аксентійчук Б.І., Алексєєнко Н.О., Андрієнко О.І., Бабов К.Д. Мінеральні води України. - К.: Купріянов А., 2005. - 576 с.

13. Моісеєв А.Ю., Дружина М.О., Моісеєва Н.П., Шестопалов В.М. Біологічні аспекти застосування природних мінеральних вод: [результати дослідж.]. - К.: КІМ, 2010. - 124 с.

14. Алексєєнко Н.О., Бабов К.Д., Гуща С.Г. Нове Нинівське родовище мінеральних вод курорту Моршин: Монографья. - Дрогобич: Коло, 2012. - 147 с.

15. Аксентійчук Б.І. Курорти та санаторії України: Науково-практ. довідник. - К.: Фолігрант, 2009. - 428 с.

16. Федорів Я.М. Фізіотерапія: навч. посіб. - Львів: Магнолія, 2011. - 542 с

17. Лобода М.В. Основи курортології. - К.: Видавець Купріянова О.О., 2003. - 511 с.

18. Рутинський М.Й. Класифрікації та типології курортів // Вісник Львівського університету. Серія географрічна. - 2007. - Вип. 34. — C. $236-246$

19. Фоменко Н.В. Рекреаційні ресурси та курортологія. - К.: Центр навчальної літератури, 2007.

20. Яцишин Р.І., Вакалюк І.П., Чернюк Н.В., Герич П.Р. Прикарпатська терапевтична школа: становлення, розвиток та важлива роль у формуванні клінічного мислення й практичного досвіду для молодого покоління // Терапевтика. — 2020. — Вип. 1 (1). — С. 23-30. 